\title{
Development of Parvalbumin-Expressing Basket Terminals in Layer II of the Rat Medial Entorhinal Cortex
}

\author{
Nina Berggaard, ${ }^{1}{ }^{-}$Ingvild E. Bjerke, ${ }^{1, *}{ }^{1}$ Anna E. B. Paulsen, ${ }^{1}{ }^{\circledR}$ Linh Hoang, ${ }^{1}$ Nan E. T. Skogaker, \\ (1) Menno P. Witter, ${ }^{2}$ and Johannes J. L. van der Want ${ }^{1}$
}

DOI:http://dx.doi.org/10.1523/ENEURO.0438-17.2018

${ }^{1}$ Department of Clinical and Molecular Medicine, Faculty of Medicine and Health Sciences, NTNU Norwegian University of Science and Technology, Trondheim 7491, Norway, ${ }^{2}$ Kavli Institute for Systems Neuroscience, Center for Computational Neuroscience, Egil and Pauline Braathen and Fred Kavli Center for Cortical Microcircuits, NTNU Norwegian University of Science and Technology, Trondheim 7491, Norway

\section{Visual Abstract}

\section{$\mathrm{PV}+$ perisomatic terminals in MEC LII}

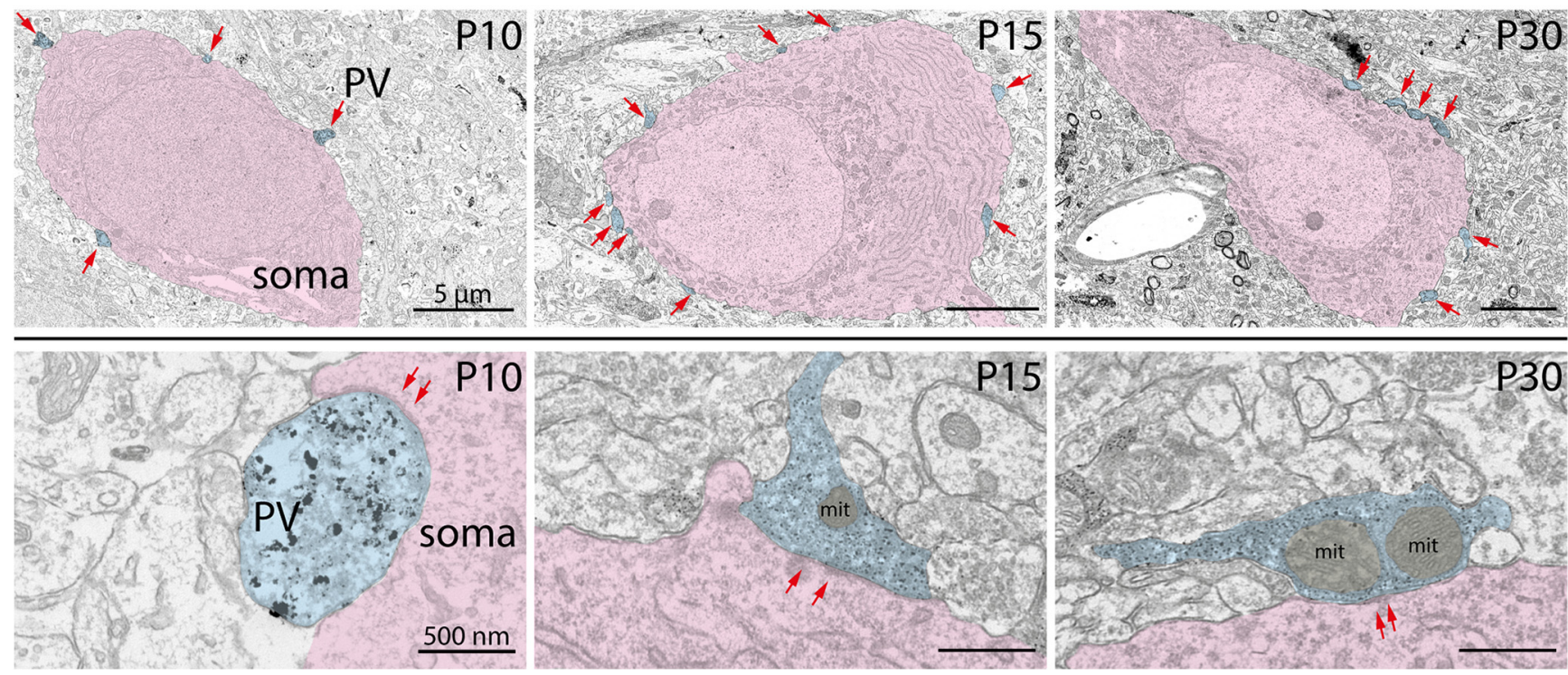

\section{Significance Statement}

Grid cells within layer II of the medial entorhinal cortex produce a regular firing pattern in response to the environment during exploration. This pattern emerges after eye-opening in rodents and exhibits a gradient along the dorsoventral axis. Input from parvalbumin-expressing $\left(\mathrm{PV}^{+}\right)$interneurons is crucial for maintaining the grid pattern; however, how the $\mathrm{PV}^{+}$innervation develops is unclear. Here we examine the structural development of dorsal and ventral perisomatic $\mathrm{PV}^{+}$terminals and target somata. We show that the size of grid-related somata and number of $\mathrm{PV}^{+}$terminals increase before eye-opening, whereas $\mathrm{PV}^{+}$terminals increase in size during grid activity stabilization. We further demonstrate that maturation in the ventral part is delayed, and that there are dorsoventral differences in young adults. 
Grid cells in layer II of the medial entorhinal cortex (MEC LII) generate multiple regular firing fields in response to the position and speed of an individual within the environment. They exhibit a protracted postnatal development and, in the adult, show activity differences along the dorsoventral axis (DVA). Evidence suggests parvalbuminpositive $\left(\mathrm{PV}^{+}\right)$interneurons, most of which are perisomatic-targeting cells, play a crucial role in generation of the hexagonal grid cell activity pattern. We therefore hypothesized that the development and organization of $\mathrm{PV}^{+}$ perisomatic terminals in MEC LII reflect the postnatal emergence of the hexagonal firing pattern and dorsoventral differences seen in grid cell activity. We used immuno-electron microscopy to examine the development of PV ${ }^{+}$ perisomatic terminals and their target somata within dorsal and ventral MEC LII in rats of postnatal day (P) $10, P 15$, and P30. We demonstrate that in dorsal and ventral MEC LII, the cross-sectional area of somata and number and density of perisomatic $\mathrm{PV}^{+}$terminals increase between $\mathrm{P} 10$ and P15. A simultaneous decrease was observed in cross-sectional area of $\mathrm{PV}^{+}$terminals. Between $\mathrm{P} 15$ and $\mathrm{P} 30$, both $\mathrm{MEC}$ regions showed an increase in $\mathrm{PV}^{+}$ terminal size and percentage of $\mathrm{PV}^{+}$terminals containing mitochondria, which may enable grid cell activity to emerge and stabilize. We also report that dorsal somata are larger and apposed by more $\mathrm{PV}^{+}$terminals than ventral somata at all stages, suggesting a protracted maturation in the ventral portion and a possible gradient in soma size and $\mathrm{PV}^{+}$basket innervation along the DVA in the adult.

\section{Key words: Developmental Biology; Medial entorhinal cortex; Parvalbumin; Synapse; Ultrastructure}

\section{Introduction}

The hippocampal formation comprises several strongly connected brain structures containing cell types with distinct activity patterns that together form the internal representation of space (Moser et al., 2008). Central to this spatial system is layer II of the medial entorhinal cortex (MEC LII), the location of most of the spatially modulated grid cells. Dependent on the position and speed of an individual, grid cells produce hexagonally arranged firing fields that form a matrix of the environment (Hafting et al., 2005). To attain the sharp onset and end of these "grid fields," grid cells require tight inhibitory control with high temporal precision by presynaptic neurons (Miao et al., 2017).

The morphologic identity of grid cells is controversial, and knowledge about synaptic connectivity in MEC LII is

Received December 15, 2017; accepted May 8, 2018; First published June 11, 2018.

The authors declare no competing financial interests.

Author contributions: N.B. and J.J.V.D.W. designed research; N.B., I.E.B., A.E.B.P., L.H., N.E.T.S., and J.J.V.D.W. performed research; N.B., M.P.W., and J.J.V.D.W. analyzed data; N.B., M.P.W., and J.J.V.D.W. wrote the paper.

CMIC is funded by the Faculty of Medicine at NTNU and Central Norway Regional Health Authority.

*Ingvild E. Bjerke is currently affiliated with the Human Brain Project at the Institute of Basic Medical Sciences, University of Oslo, Norway. The QuickNII Software Tool is distributed by the Human Brain Project, Funded by the European Union's Horizon 2020 Research and Innovation Programme under grant agreement no. 720270 (HBP SGA1)

Acknowledgments: We thank Grethe Mari Olsen, Ph.D., Kavli Institute for Systems Neuroscience, Norwegian University of Science and Technology, for providing the perfusion fixed brains. The electron microscopy work was performed at the Cellular and Molecular Imaging Core Facility (CMIC), Norwegian University of Science and Technology (NTNU).

Correspondence should be addressed to Johannes J.L. van der Want, Department of Clinical and Molecular Medicine, Faculty of Medicine and Health Sciences, Norwegian University of Science and Technology, Trondheim, 7491, Norway. E-mail: johannes.want@ntnu.no.

DOI:http://dx.doi.org/10.1523/ENEURO.0438-17.2018

Copyright @ 2018 Berggaard et al.

This is an open-access article distributed under the terms of the Creative Commons Attribution 4.0 International license, which permits unrestricted use, distribution and reproduction in any medium provided that the original work is properly attributed. limited. It has been found that the MEC LII microcircuitry is strikingly inhibitory, with few direct excitatory connections between principal cells (Couey et al., 2013; Pastoll et al., 2013; Fuchs et al., 2015). Supporting evidence indicates that the most common type of inhibitory cell, the parvalbumin expressing $\left(\mathrm{PV}^{+}\right)$interneuron, provides strong regulation of grid cells through monosynaptic inputs (Buetfering et al., 2014; Miao et al., 2017). PV ${ }^{+}$ interneurons are fast-spiking and GABAergic, and although $\mathrm{PV}^{+}$cells comprise several subtypes, the majority are basket cells targeting perisomatic regions (Baude et al., 2007).

Grid cell activity has a specific timeline of maturation and displays dorsoventral differences. In rodents, for instance, grid cells do not start to exhibit a stable hexagonal activity pattern before postnatal day 16 (P16). However, after this time point, there is a rapid increase in number of mature grid cells, reaching close to adult levels around P22 (Langston et al., 2010; Wills et al., 2010, 2012). Electrophysiological recordings have demonstrated that the size of grid fields and the distance between them increases along the dorsoventral axis (DVA) of MEC LII (Brun et al., 2008; Stensola et al., 2012). These spatiotemporal differences in grid cell activity likely reflect differences in connectivity within MEC LII. Interestingly, concomitant with the increase in grid field size and spacing, there is a decrease in overall number of $\mathrm{PV}^{+}$terminals in MEC LII along the DVA, although the number of GABAergic terminals remains constant (Beed et al., 2013). Moreover, the DVA exhibits a gradient in maturation, with dorsal neurons developing before ventral ones (Ray and Brecht, 2016; Donato et al., 2017). Considering the putative involvement of $\mathrm{PV}^{+}$basket cells in modulating grid cell activity, we hypothesized that synaptic innervation by $\mathrm{PV}^{+}$basket cells would display changes during postnatal development and along the DVA that parallel the spatiotemporal differences in grid cell activity. We used immuno-electron microscopy to investigate and perform quantitative analysis of the structural maturation of cell somata and $\mathrm{PV}^{+}$basket cell terminals apposing these somata in the dorsal and ventral portions of MEC LII. 

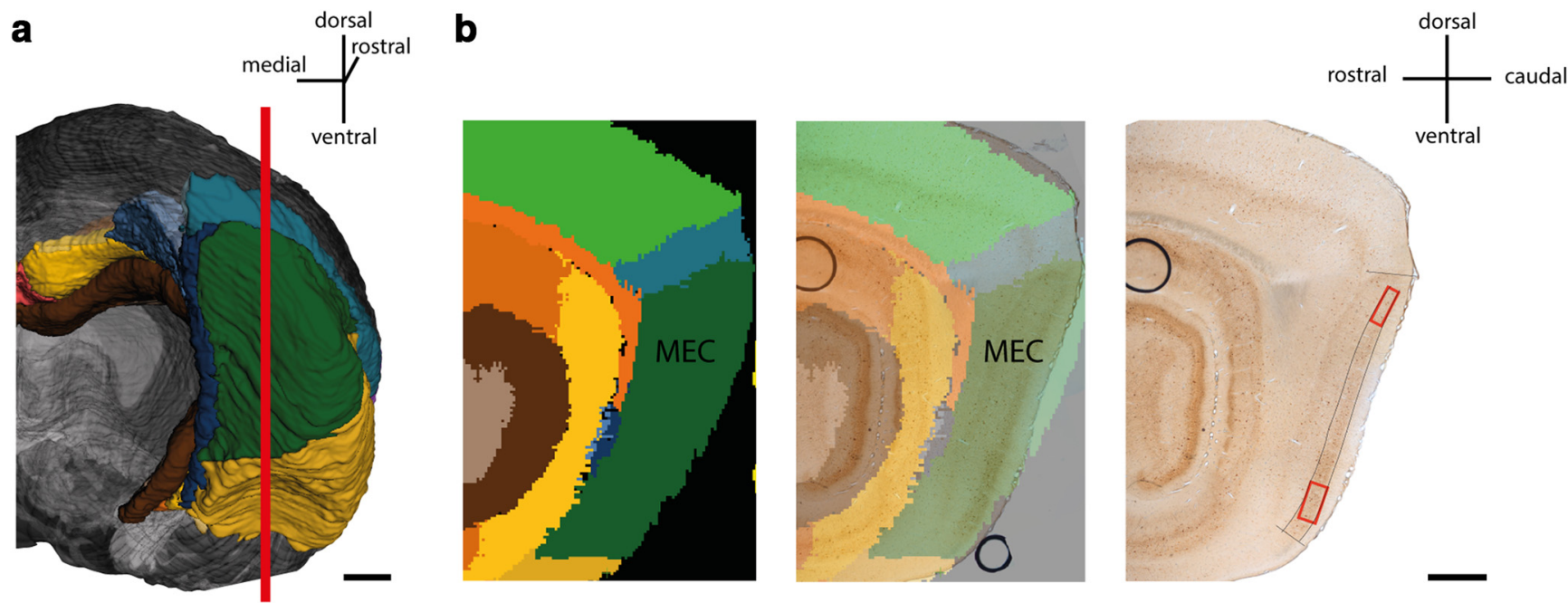

Figure 1. Position of regions of interest used for immuno-electron microscopy. a, Caudal view of rat brain, right hemisphere, without cerebellum, made by using the Waxholm Space Atlas (Kjonigsen et al., 2015; Papp et al., 2014). Red line signifies cutting plane, showing region from which parasagittal sections used in the study were taken. a, Example of parasagittal section of the caudal part of rat brain. Left: Waxholm Space Atlas representation showing subdivisions. Middle: Waxholm Space Atlas representation superimposed onto $\mathrm{PV}^{+}$immunolabeled section used in study. Right: A corresponding $\mathrm{PV}^{+}$immunolabeled vibratome section. Black lines delineate MEC LII. Red boxes show the dorsal and ventral positions from which the tissue was processed for further analysis. Scale bars: $1 \mathrm{~mm}$.

\section{Materials and Methods}

\section{Animals and tissue processing}

Five male Long-Evans rats provided by the Norwegian University of Science and Technology were studied from P10 (two rats), P15 (one rat), and P30 (two rats). All animal procedures were performed in accordance with the Norwegian University of Science and Technology animal care committee's regulations. The rats lived in a controlled environment with lights on from 8:00 PM to 8:00 AM, and with food and water available ad libitum. P30 rats were anaesthetized with $4 \%-5 \%$ isofluorane in 1 liter $\mathrm{O}_{2} / \mathrm{min}$ with a subsequent overdose of pentobarbital, and the rats at P10 and P15 were kept anaesthetized with 0.5 liter $\mathrm{O}_{2} /$ min. When the absence of reflexes was confirmed, transcardial perfusion was performed with fresh Ringer's solution comprising $145 \mathrm{~mm} \mathrm{NaCl}, 3 \mathrm{~mm} \mathrm{KCl}$, and $2 \mathrm{~mm}$ $\mathrm{NaHCO}_{4}$. The $\mathrm{pH}$ of the solution was adjusted to 6.9. The perfusion fluid was changed to cold $4 \%$ paraformaldehyde (PFA; Merck) and $0.1 \%$ glutaraldehyde (GA; Merck) in $0.1 \mathrm{M}$ PBS. Brains were removed from the skull, postfixed in the same solution at $4^{\circ} \mathrm{C}$ for at least $12 \mathrm{~h}$, and stored in $0.1 \mathrm{M}$ PBS until further processing. All perfusions were performed at noon $\pm 2 \mathrm{~h}$.

The brains were rinsed in cold 125-mM PBS, and 60$\mu \mathrm{m}$-thick parasagittal sections were cut using a vibratome (Leica VT1000S). Sections containing the region of interest were collected and postfixed in 4\% PFA and $0.1 \%$ GA in $0.1 \mathrm{M}$ PBS for $2 \mathrm{~h}$ before being stored at $4^{\circ} \mathrm{C}$ in $125 \mathrm{~mm}$ PBS. The anatomic location of the vibratome sections was determined by spatial registration of section images to the Waxholm Space atlas of the rat brain (Papp et al., 2014; Kjonigsen et al., 2015) using the software tool QuickNII (Puchades et al., 2017). The vibratome sections selected for electron microscopy were mapped to the lateral part of the temporal lobe at atlas levels $375-380$ (corresponding to a distance of $190 \mu \mathrm{m}$ in the atlas), and the locations of the blocks taken for electron microscopy were thus confirmed to be situated within the MEC (Fig. $1 a, b)$.

\section{Immuno-electron microscopy}

Sections were rinsed in $0.1 \mathrm{M}$ phosphate buffer $(\mathrm{PB})$ and incubated in $0.1 \mathrm{M}$ PB $+0.05 \%$ Triton X-100 $(0.05 \%$ $\mathrm{PB}-\mathrm{Tr} X$ ) for $20 \mathrm{~min}$. After rinsing in $0.1 \mathrm{M} \mathrm{PB}$, endogenous peroxidase activity was blocked with $1 \% \mathrm{H}_{2} \mathrm{O}_{2}$ and $50 \%$ methanol in $0.1 \mathrm{M} \mathrm{PB}$ for $30 \mathrm{~min}$. Sections were then rinsed and incubated in a solution of 1\% BSA (SigmaAldrich, A7034), 1\% normal horse serum (NHS, Swant, H0146) and $0.05 \%$ PB-TrX for 1-1.5 h. Because of the more fragile tissue, Triton $X-100$ was not included in the PB buffer for P10 rats. Next, sections were incubated overnight at $4^{\circ} \mathrm{C}$ with polyclonal goat anti-parvalbumin (Swant, PVG 214 RRID:AB_10000345) diluted 1:40,000 in $1 \%$ BSA and $1 \%$ NHS. The following day, the sections were rinsed and incubated in biotinylated horse anti-goat IgG (Vector Laboratories, BA-9500, also BA9500 RRID: $\left.A B \_2336123\right)$ at 1:400 for $2 \mathrm{~h}$ at room temperature. After rinsing, sections were incubated with avidin-biotinperoxidase (Vectastain ABC kit standard, Vector Laboratories, PK-4000 RRID:AB_2336818) in $0.1 \mathrm{M}$ PB for $1 \mathrm{~h}$ at room temperature, with subsequent rinsing in $0.1 \mathrm{M} \mathrm{PB}$ and staining in the dark with filtered $0.03 \%$ 2,3diaminobenzidine (DAB; Sigma-Aldrich) and $0.01 \% \mathrm{H}_{2} \mathrm{O}_{2}$ in $0.1 \mathrm{M}$ PB. When labeled cells were clearly visible, the reaction was stopped with another round of rinsing in buffer. After microscopic inspection, images were taken for later reference. Glassware washed in a hydrochloric acid solution was hereafter used during the subsequent silver development and gold toning, and all solutions were 
diluted with Milli-Q water. After rinsing in $2 \%$ sodium acetate (Sigma, S8750), sections were kept in 10\% sodium thioglycolate (Sigma, T0632) overnight at $4^{\circ} \mathrm{C}$. Sections were then rinsed in $2 \%$ sodium acetate. Immunoreactivity was enhanced according to the goldsubstituted silver peroxidase method (van den Pol and Gorcs, 1986). In short, after rinsing in $2 \%$ sodium acetate, sections were incubated in the freshly prepared silver development solution for 7-8 min, after which the silver development was stopped by a $2-$ min rinse in $1 \%$ acetic acid. Sections were then rinsed in sodium acetate, followed by a $15-$ min incubation in $0.05 \%$ gold chloride. After another rinse in sodium acetate, sections were incubated in 3\% sodium thiosulfate and rinsed in sodium acetate.

\section{Postfixation and embedding}

Sections were rinsed in $0.1 \mathrm{M}$ cacodylate buffer and postfixed in $1 \% \mathrm{OsO}_{4}$ and $1.5 \% \mathrm{~K}_{4} \mathrm{Fe}(\mathrm{CN})_{6}$ in $0.1 \mathrm{M}$ cacodylate for $15 \mathrm{~min}$. Another rinse in $0.1 \mathrm{M}$ cacodylate buffer ensued before the sections were dehydrated in an ascending concentration of ethanol and embedded in epoxy resin (LX 112, Ladd Research Industries) according to standard protocols. Sections were flat-embedded between two Aclar sheets at $60^{\circ} \mathrm{C}$ overnight. Regions of interest along the dorsoventral axis of MEC LII were carefully cut out and glued with epoxy resin onto polymerized epoxy stubs (Fig. 1b). After polymerization, ultrathin sections of MEC LIl were cut using a Leica UC6 Ultramicrotome. Thin sections were collected on 200-mesh thinbar copper grids and contrasted with 4\% uranyl acetate and $1 \%$ lead citrate. Sections were inspected with a transmission electron microscope (JEOL JEM-1011) and imaged using a digital Morada camera.

\section{Measurements of perisomatic $\mathrm{PV}^{+}$terminals and $\mathrm{PV}^{-}$ somata}

Selected samples of entorhinal cortex were taken from at least two different $60-\mu \mathrm{m}$ vibratome sections per age group to obtain independent measurements. To target principal cells of LII, care was taken to select PVimmunonegative somata from deep to superficial LII. To be included for the measurements, cells had to contain a nucleus, and the perisomatic $\mathrm{PV}^{+}$terminals had to display immunolabeling. The synaptic membrane had to be rigidly apposed to the somatic membrane and contain electron dense pre- and postsynaptic specializations exhibited as a membrane widening. Because of the immunolabeling treatment with $\mathrm{DAB}$ and silver-gold precipitate, vesicles were not always visible. The cross-sectional area of somata and $\mathrm{PV}^{+}$perisomatic terminals was measured, and the percentage of cross-sectional somata apposed by $\mathrm{PV}^{+}$terminals was calculated. Somata not apposed by $\mathrm{PV}^{+}$terminals were excluded to find the average number of $\mathrm{PV}^{+}$terminals forming perisomatic synaptic contacts per soma and when calculating the density of $\mathrm{PV}^{+}$terminal apposition, which was done by dividing the total length of $\mathrm{PV}^{+}$terminal membrane apposed to a soma by the soma perimeter and multiplying by 100 . Finally, the number of perisomatic $\mathrm{PV}^{+}$terminals containing mitochondria was divided by the total number of perisomatic
$\mathrm{PV}^{+}$terminals and multiplied by 100 to get the percentage of $\mathrm{PV}^{+}$terminals containing mitochondria. All measurements were performed using iTEM software (Olympus 5.0)

\section{Statistical analysis}

As the cross-sectional area of somata in the ventral part of MEC LII showed a homogeneous variance and normal distribution, the differences over time were assessed with one-way ANOVA and Tukey's post hoc test. The crosssectional area of somata in the dorsal MEC LII did not display a homogeneous variance; therefore, Welch ANOVA and Games-Howell post hoc tests were used to assess developmental differences. An independent $t$ test was used to evaluate differences between dorsal and ventral MEC LII and between animals of same age group. Statistical differences in the percentage of cross-sectional somata apposed by $\mathrm{PV}^{+}$terminals and percentage of $\mathrm{PV}^{+}$ terminals containing mitochondria were determined by Pearson $\chi^{2}$ tests. Because all other variables lacked a normal distribution and homogeneous variance, KruskalWallis $H$ tests and Mann-Whitney $U$ tests were performed to assess developmental differences, whereas differences between dorsal and ventral regions and between animals of same age groups were examined using Mann-Whitney $U$ tests. All statistics were performed using IBM SPSS version 25.0.0.1, and statistical significance was set to $p$ $\leq 0.05$.

\section{Results}

We investigated the development of $\mathrm{PV}^{+}$basket cellrelated network within MEC LII by measuring the crosssectional area of PV immunonegative somata and counting the number of perisomatic $\mathrm{PV}^{+}$terminals (hereafter simply referred to as $\mathrm{PV}^{+}$terminals) in dorsal and ventral LII of rats at P10 $(n=2), \mathrm{P} 15(n=1)$, and P30 $(n$ $=2$ ). Cell somata in layer II were spherical, ovoid, or elongated in shape and less frequently classified as multipolar or fusiform. Somata in the plane of sectioning including a nucleus were used for measurements, assuming that this would give a midcentral representation of the terminal input on that soma. At all three postnatal stages, but more frequently at P15 and P30, cells were apposed by $\mathrm{PV}^{+}$terminals, which formed symmetric synapses and which contained varying degrees of labeling (Fig. 2).

\section{Soma cross-sectional area}

Dorsal and ventral cells in MEC LII displayed changes in cross-sectional soma area during development, as determined by Welch ANOVA $\left(F_{(2,83.524)}=14.512, p<0.001\right)$ and one-way ANOVA $\left(F_{(2,136)}=12.422, p<0.001\right)$, respectively. The largest increment occurred between P10 and $\mathrm{P} 15$, with a $30.9 \%$ increase in cross-sectional soma area in dorsal LII ( $p=0.010$, Games-Howell post hoc test) and a $27.3 \%$ increase in ventral LII $(p<0.001$, Tukey's post hoc test). The cross-sectional soma area did not increase significantly between P15 and P30, although there was still a slightly larger growth in the dorsal part (12.1\%) compared to the ventral one (2.6\%; Table 1; Fig. $3 a)$. The cross-sectional area of dorsal somata was consistently larger compared with ventral somata, either 


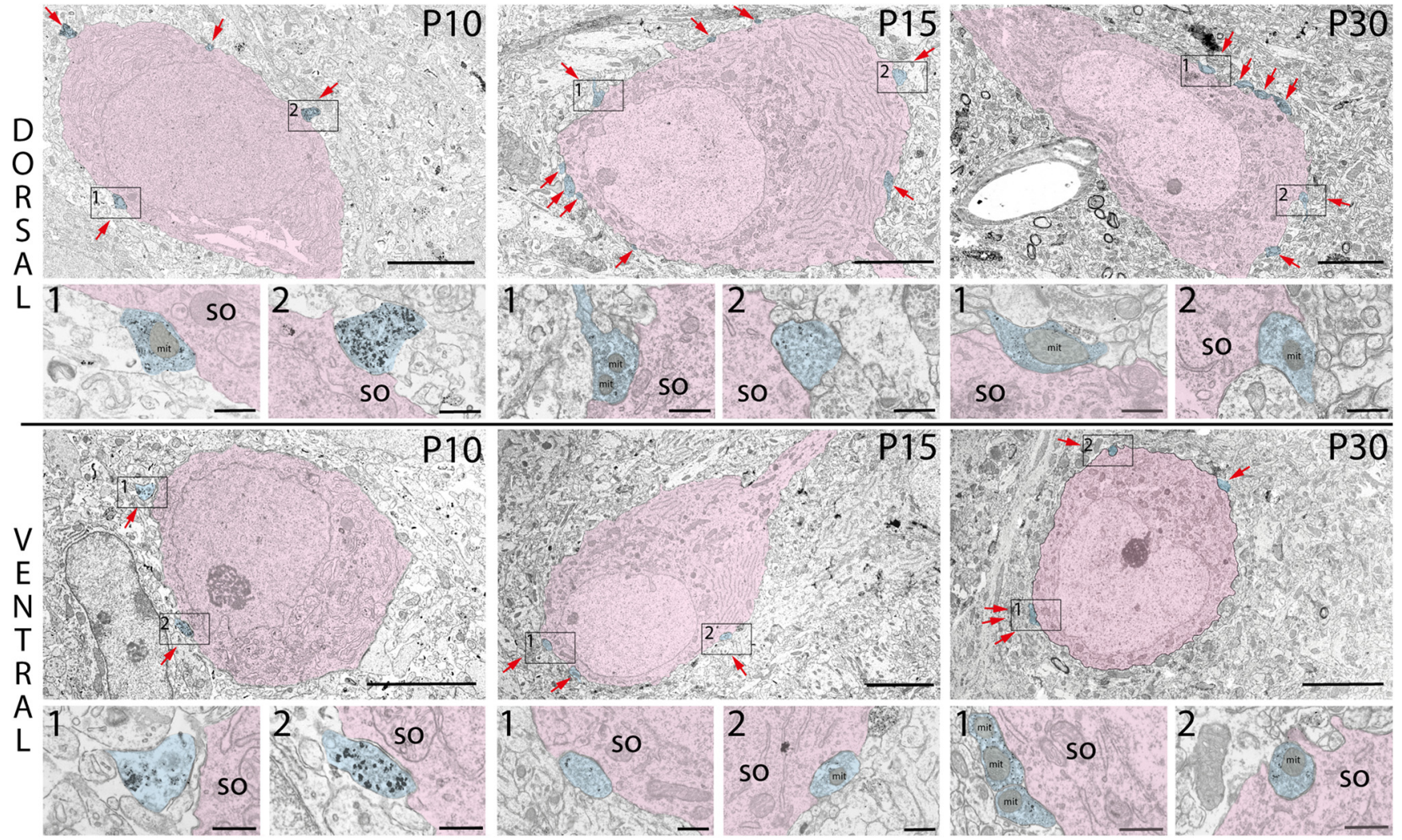

Figure 2. Typical neuronal somata within the dorsal and ventral portion of MEC LII at P10, P15, and P30. PV ${ }^{+}$terminals (blue) forming synaptic contact onto somata (pink) are indicated by red arrows. The boxes indicate $\mathrm{PV}^{+}$terminals shown in the enlarged figures just below the low-magnification images of the somata. Note that the ventral soma at P10 is apposed by only one $\mathrm{PV}^{+}$terminal; thus, the first close-up image is of a $\mathrm{PV}^{+}$labeled profile in the vicinity. so, soma; mit, mitochondria. Scale bars: images of somata, $5 \mu \mathrm{m}$; images of $\mathrm{PV}^{+}$terminals, $500 \mathrm{~nm}$.

$31.1 \%(\mathrm{P} 10, t(62.9)=3.52, p=0.001$, independent $t$ test), 34.8\% (P15, $t(56.8)=3.72, p<0.001$, independent $\mathrm{t}$ test), or $47.2 \%(\mathrm{P} 30, t(76.0)=6.04, p<0.001$, independent $\mathrm{t}$ test; Table 1; Fig. 3b).

\section{Number and density of $\mathrm{PV}^{+}$terminals}

At P10, and to a larger extent in the ventral portion of MEC LII $\left(\chi^{2}(1)=16.765, p<0.001\right)$, cross-sectional somata absent of $\mathrm{PV}^{+}$terminal apposition were frequently

Table 1. Cross-sectional soma area, percentage of soma sections with $\mathrm{PV}^{+}$terminal apposition, number of $\mathrm{PV}^{+}$perisomatic terminals per cell per thin section, and $\mathrm{PV}^{+}$terminal density at P10, P15, and P30 in dorsal and ventral MEC LII

\section{Age, postnatal days}

Cross-sectional area of somata $\left(\mu \mathrm{m}^{2}\right)$

10

15

30

Soma cross-sections with $\mathrm{PV}^{+}$terminal apposition

10

15

30

Number of $\mathrm{PV}^{+}$perisomatic terminals

10

15

30

$\mathrm{PV}^{+}$terminal density (\%)

10

15

30

Mean \pm SEM or
Dorsal
$172.94 \pm 10.03(39)$
$226.35 \pm 14.56(44)+11.49(47)$
$253.62 \pm 19$
$82.1(39)$
$100(44)$
$100(47)$
$2.22 \pm 0.28(32)$
$6.34 \pm 0.52(44)$
$5.74 \pm 0.44(47)$
$3.64 \pm 0.38(32)$
$8.93 \pm 0.62(44)$
$8.71 \pm 0.70(47)$

Ventral

$131.91 \pm 5.94(47)$

$167.89 \pm 5.90(46)$

$172.29 \pm 7.04(46)$

$38.3(47)$

$95.6(46)$

$95.6(46)$

$1.28 \pm 0.11(18)$

$3.25 \pm 0.22(44)$

$4.23 \pm 0.36(44)$

$2.58 \pm 0.30(18)$

$5.50 \pm 0.41(44)$

$6.97 \pm 0.60(44)$

$\mathrm{PV}^{+}$terminal density was calculated by dividing the total length of $\mathrm{PV}^{+}$terminal membrane apposed to a given cross-sectional soma by the perimeter of that soma and multiplying by 100 . 

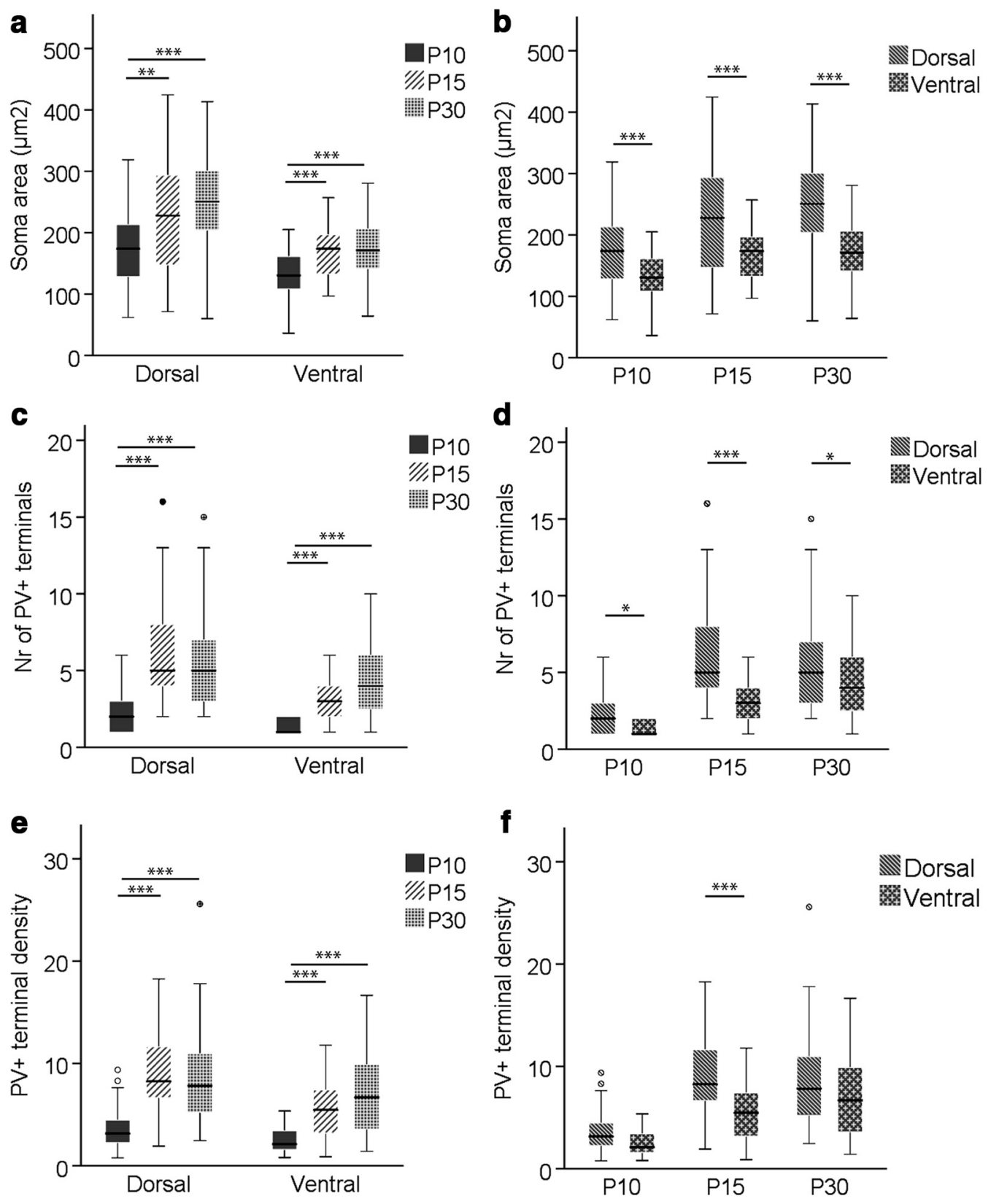

Figure 3. Box-and-whisker plots showing cross-sectional area of somata and number and density of $\mathrm{PV}^{+}$perisomatic terminals per cell per thin section at P10, P15, and P30 in dorsal and ventral MEC LII. a, c, e, Changes in average cross-sectional soma area and number and density of $\mathrm{PV}^{+}$terminals, respectively, during ontogeny in dorsal and ventral LII. $\boldsymbol{b}, \boldsymbol{d}, \boldsymbol{f}$, Dorsoventral differences in average cross-sectional soma area and number and density of $\mathrm{PV}^{+}$terminals, respectively, per time point. The middle bar of each box plot represents the population median, and the 25th and 75th percentiles are represented by the lower and upper boundaries of the boxes, respectively. The minimum and maximum values are represented by the lower and upper ends of the whiskers. Dots represent outliers, i.e., values that exceeded the 75 th percentile $+1.5 \times(75$ th percentile -25 th percentile). $*, p \leq 0.05 ; * *, p \leq 0.01$; $* * *, p \leq 0.001$.

observed. Between P10 and P15, there was an increase in percentage of cross-sectional somata apposed by $\mathrm{PV}^{+}$ terminals in the dorsal $\left(82.1 \%\right.$ to $100 \%, \chi^{2}(1)=8.625, p$ $=0.003)$ and ventral $\left(38.3 \%\right.$ to $95.6 \%, \chi^{2}(1)=34.413, p$ $<0.001$; Table 1) portion. To measure the average number and density of $\mathrm{PV}^{+}$terminals per cross-sectional soma, only somata apposed by $\mathrm{PV}^{+}$terminals were included. Kruskal-Wallis $H$ tests revealed statistically significant changes during development in the number of
$\mathrm{PV}^{+}$terminals per cross-sectional soma in dorsal $\left(\chi^{2}(2)=\right.$ 43.157, $p<0.001)$ and ventral $\left(\chi^{2}(2)=30.346, p<0.001\right)$ LII. The largest increase was between P10 and P15 in dorsal $(185.6 \%, U=143, p<0.001$, Mann-Whitney $U$ test) and ventral $(153.9 \%, U=82.5, p<0.001$, MannWhitney $U$ test) part of MEC LII. Between P15 and P30, the dorsal and ventral MEC LII showed opposing trends, with a slight decrease in the dorsal part $(-9.5 \%)$ and an increase (30.2\%) in the ventral part (Table 1; Fig. 3c). The 

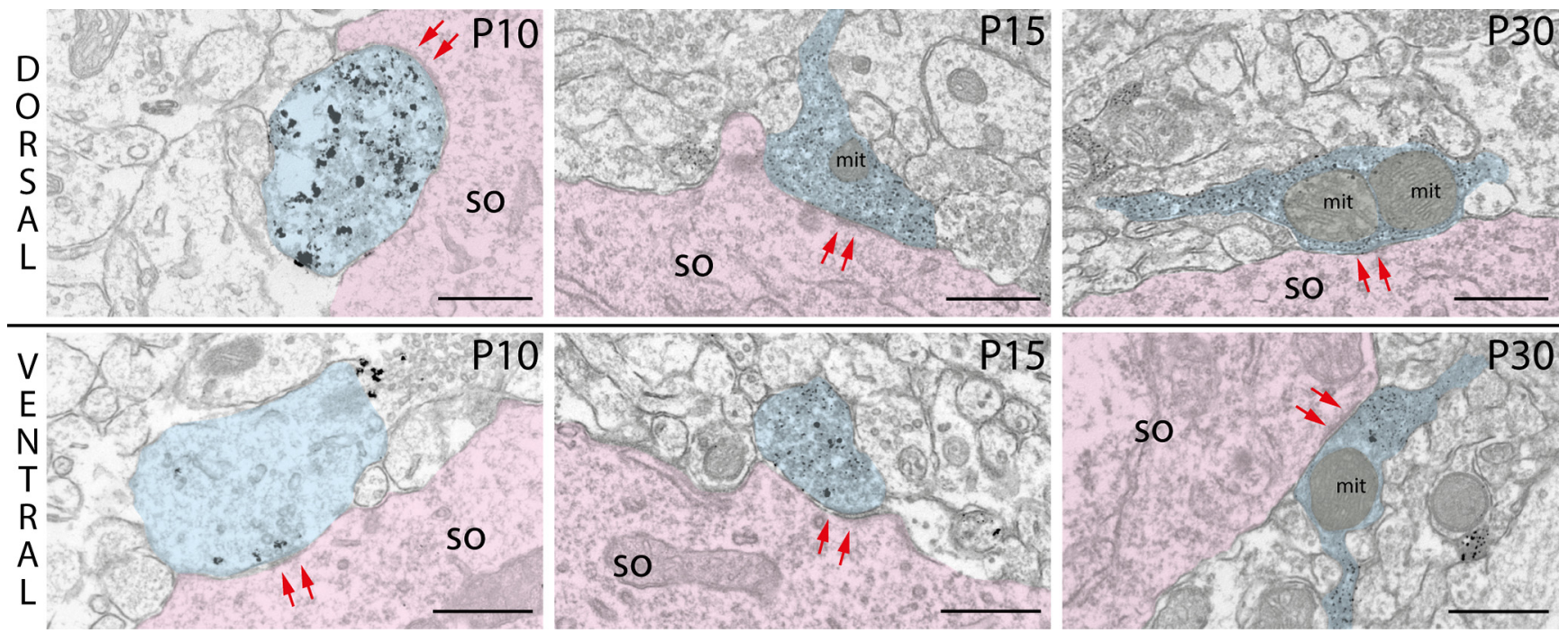

Figure 4. Cross-sections of typical $\mathrm{PV}^{+}$terminals in dorsal and ventral part of MEC LII at P10, P15, and P30. Arrows (red) indicate synaptic contacts between $\mathrm{PV}^{+}$terminals (blue) and somata (pink). so, soma; mit, mitochondria. Scale bars: $500 \mathrm{~nm}$.

number of $\mathrm{PV}^{+}$terminals per cross-sectional soma in dorsal LII was significantly higher than in ventral LII at all three time points $(\mathrm{P} 10: U=181.0, p=0.017 ; \mathrm{P} 15 ; U=$ 393.5, $p<0.001$; P30: $U=743.5, p=0.02$, MannWhitney $U$ test; Table 1; Fig. 3d).

Regarding the density of $\mathrm{PV}^{+}$terminals, calculated by dividing the total length of $\mathrm{PV}^{+}$terminal membrane apposed to a given soma by the perimeter of that soma and multiplying by 100 , we noticed an ontogenetic change similar to that of the mean number of $\mathrm{PV}^{+}$terminals (dorsal, $\chi^{2}(2)=38.645, p<0.001$; ventral, $\chi^{2}(2)=22.543$, $p<0.001$, Kruskal-Wallis $H$ test), with a statistically significant increase between $\mathrm{P} 10$ and $\mathrm{P} 15$ in dorsal (145.3\%, $U=179, p<0.001$, Mann-Whitney $U$ test) and ventral $(113.2 \%, U=142, p<0.001$, Mann-Whitney $U$ test) LII. Neither dorsal nor ventral LII showed significant changes between $\mathrm{P} 15$ and $\mathrm{P} 30$ in $\mathrm{PV}^{+}$terminal density (Table 1; Fig. 3e). Somata in the dorsal part of LII had significantly larger $\mathrm{PV}^{+}$terminal density than ventral somata at $\mathrm{P} 15(U=478, p<0.001$, Mann-Whitney $U$ test $)$, but not at $\mathrm{P} 10(U=210, p=0.115$, Mann-Whitney $U$ test $)$ and P30 $(U=823, p=0.094$, Mann-Whitney $U$ test; Table 1; Fig. 3f).

\section{Maturation of $\mathrm{PV}^{+}$terminals}

To investigate the maturation process of $\mathrm{PV}^{+}$basket innervation, we measured the cross-sectional area of terminals and calculated the percentage of $\mathrm{PV}^{+}$terminals containing mitochondria within dorsal and ventral MEC LII at P10, P15, and P30. Cross-sections of typical terminals found in the dorsal and ventral MEC are shown in Fig. 4.

The cross-sectional area of $\mathrm{PV}^{+}$terminals showed significant differences between groups in both dorsal $\left(\chi^{2}(2)\right.$ $=49.776, p<0.001)$ and ventral $\left(\chi^{2}(2)=18.794, p<\right.$ $0.001)$ MEC LII, as determined by Kruskal-Wallis $H$ tests. On average, the cross-sectional area of $\mathrm{PV}^{+}$terminals was largest at P10 in dorsal and ventral parts of LII, with a significant decrease in cross-sectional area until P15 (dorsal: $-30.8 \%, U=10,743, p<0.001$; ventral: $-45.8 \%$, $U=1020, p=0.002$, Mann-Whitney $U$ test). In both regions of LII, this decrease was followed by a significant increase in area of $\mathrm{PV}^{+}$terminals between P15 and P30 (dorsal, $U=20456, p<0.001$; ventral, $U=11276, p<$ 0.001 , Mann-Whitney $U$ test), such that in the dorsal portion, $\mathrm{PV}^{+}$terminals at $\mathrm{P} 30$ and $\mathrm{P} 10$ were of approximately the same size. For the ventral portion, however, $\mathrm{PV}^{+}$terminals were significantly smaller at P30 than at P10 $(U=1663, p=0.043$, Mann-Whitney $U$ test; Table 2;

Table 2. Cross-sectional area of $\mathrm{PV}^{+}$terminals and percentage of $\mathrm{PV}^{+}$terminals containing mitochondria at $\mathrm{P} 10$, $\mathrm{P} 15$, and $\mathrm{P} 30$ in dorsal and ventral MEC LII

Age, postnatal days

Cross-sectional area of $\mathrm{PV}^{+}$perisomatic terminals $\left(\mu \mathrm{m}^{2}\right)$

10

15

30

$\mathrm{PV}^{+}$terminals containing mitochondria

10

15

30

$\begin{array}{ll}\begin{array}{l}\text { Mean } \pm \text { SEM or \% ( } n \text { terminals) } \\ \text { Dorsal }\end{array} & \text { Ventral } \\ 0.52 \pm 0.04(98) & 0.59 \pm 0.10(23) \\ 0.36 \pm 0.02(294) & 0.32 \pm 0.02(149) \\ 0.51 \pm 0.02(217) & 0.38 \pm 0.01(195) \\ 36.7(98) & 30.4(23) \\ 39.1(294) & 30.9(149) \\ 65.4(217) & 63.6(195)\end{array}$



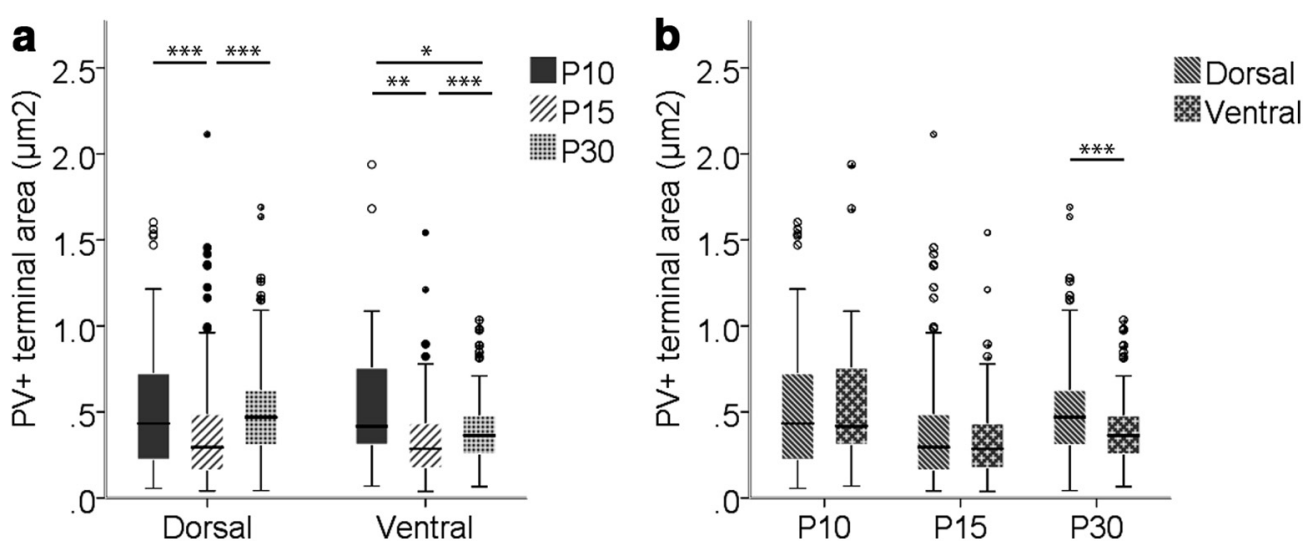

Figure 5. Box-and-whisker plots of the cross-sectional area of $\mathrm{PV}^{+}$terminals at P10, P15, and P30 in dorsal and ventral MEC LII. a, Changes during development of the cross-sectional area of $\mathrm{PV}^{+}$terminals in dorsal and ventral MEC LII. $\boldsymbol{b}$, Dorsoventral differences per time point. The middle bar of each box plot represents the population median, and the 25th and 75th percentiles are represented by the lower and upper boundaries of the boxes, respectively. The minimum and maximum values are represented by the lower and upper ends of the whiskers. Dots represent outliers, i.e., values that exceeded the 75 th percentile $+1.5 \times(75$ th percentile -25 th percentile). $*, \mathrm{p} \leq 0.05 ; * *, \mathrm{p} \leq 0.01 ; * * *, \mathrm{p} \leq 0.001$.

Fig. 5a). The cross-sectional area of $\mathrm{PV}^{+}$terminals was similar in dorsal and ventral parts of LII at P10 and P15. However, the smaller relative increase in cross-sectional area of ventral $\mathrm{PV}^{+}$terminals than of dorsal $\mathrm{PV}^{+}$terminals between P15 and P30 caused a significant difference in $\mathrm{PV}^{+}$terminal size between dorsal and ventral MEC LII at P30 $(U=15259, p<0.001$, Mann-Whitney $U$ test; Table 2; Fig. 5b).

The percentage of $\mathrm{PV}^{+}$terminals containing mitochondria remained at $35 \%-40 \%$, and $30 \%-31 \%$ between $\mathrm{P} 10$ and P15 in the dorsal and ventral part of LII, respectively. Between P15 and P30, however, there was an increase to $65.4 \%$ in dorsal LII $\left(\chi^{2}(1)=34.602, p<0.001\right.$, Pearson $\chi^{2}$ test) and $63.6 \%$ in ventral LII until P30 $\left(\chi^{2}(1)=36.169, p\right.$ $<0.001$, Pearson $\chi^{2}$ test). The percentage of $\mathrm{PV}^{+}$terminals containing mitochondria was not significantly different between dorsal and ventral regions of MEC LII between P10 and P30 (Table 2).

To examine whether the results for developmental changes or dorsoventral differences could be affected by potential differences between animals of the same age group, we compared the means between the individual P10 and individual P30 animals for all variables. This was done by using either independent $t$ tests or, in the absence of homogeneous variances, nonparametric MannWhitney $U$ tests. Only variables that were significantly different between animals of the same age group are shown (Table 3). Significant differences were found between the two P30 animals, as one animal had $33.4 \%$ fewer $\mathrm{PV}^{+}$terminals per soma per thin section than the other animal. These terminals were in addition 12.8\% larger than those of the second animal. Additional differences were found between P10 animals, as ventral cells of one animal were on average $37.1 \%$ larger than those of the second animal.

\section{Discussion}

A crucial component for maintaining the spatial tuning of grid cells is the strong inhibitory input they receive by $\mathrm{PV}^{+}$interneurons (Buetfering et al., 2014; Miao et al., 2017). To investigate the structural postnatal development of $\mathrm{PV}^{+}$basket cell perisomatic connectivity and targeted somata within the dorsal and ventral part of MEC LII, we selectively labeled vibratome sections from rats at P10, P15, and P30 with PV antibody and processed them for electron microscopy. We report that the development between P10 and P30 in dorsal and ventral MEC LII follows a similar course, with an increase in soma crosssectional area and number and density of $\mathrm{PV}^{+}$terminals occurring between P10 and P15. This increase in number and density of $\mathrm{PV}^{+}$terminals occurs in parallel with a reduction in average cross-sectional area of the $\mathrm{PV}^{+}$ter-

Table 3. Statistically significant differences in $\mathrm{PV}^{+}$terminals and somata between animals of same age group

\begin{tabular}{|c|c|c|c|c|c|}
\hline \multirow[b]{2}{*}{ Variable } & \multirow[b]{2}{*}{ Age, days } & \multicolumn{4}{|c|}{ Mean \pm SEM $(n)$} \\
\hline & & $\begin{array}{l}\text { Region of } \\
\text { MEC LII }\end{array}$ & Animal 1 & Animal 2 & $\begin{array}{l}\text { Test statistics } \\
\text { and } p \text { value }\end{array}$ \\
\hline $\begin{array}{l}\text { Soma cross-sectional } \\
\text { area }\left(\mu \mathrm{m}^{2}\right)\end{array}$ & 10 & Ventral & $\begin{array}{l}152.06 \pm 6.68 \\
(24 \text { cells })\end{array}$ & $\begin{array}{l}110.88 \pm 7.91 \\
(23 \text { cells })\end{array}$ & $\begin{array}{r}t(45)=3.99 \\
p<0.001\end{array}$ \\
\hline $\begin{array}{l}\text { Number of } \mathrm{PV}^{+} \\
\text {terminals }\end{array}$ & 30 & Dorsal & $\begin{array}{l}4.74 \pm 0.43 \\
\quad(27 \text { cells })\end{array}$ & $\begin{array}{l}7.10 \pm 0.78 \\
\quad(20 \text { cells })\end{array}$ & $\begin{array}{l}U=160 \\
p=0.017\end{array}$ \\
\hline $\begin{array}{l}\mathrm{PV}^{+} \text {terminal cross-sectional } \\
\text { area }\left(\mu \mathrm{m}^{2}\right)\end{array}$ & 30 & Dorsal & $\begin{array}{l}0.53 \pm 0.28 \\
\quad(128 \text { terminals })\end{array}$ & $\begin{array}{l}0.47 \pm 0.25 \\
\quad(89 \text { terminals })\end{array}$ & $\begin{array}{l}U=4781 \\
p=0.044\end{array}$ \\
\hline
\end{tabular}

The differences between individual animals of the same age group are shown, along with associated $p$ values derived from independent $t$ test (soma crosssectional area) or Mann-Whitney $U$ test (all other variables). 
minals. Between $\mathrm{P} 15$ and $\mathrm{P} 30, \mathrm{PV}^{+}$terminals show an increase in cross-sectional area and percentage containing mitochondria. We also report that dorsal somata of layer II principal neurons are larger and apposed by more $\mathrm{PV}^{+}$terminals than ventral somata at all developmental stages.

\section{$\mathrm{PV}^{+}$innervation of principal cells in MEC LII}

At P10, and especially in the ventral portion of MEC LII, we found somata that were not contacted by $\mathrm{PV}^{+}$terminals. However, at P15 and P30, $\mathrm{PV}^{+}$terminals formed symmetric synapses with almost all somata, in line with a previous immuno-electron microscopy study in the adult rat MEC (Wouterlood et al., 1995). Although we did not selectively identify somata, a substantial portion of them likely includes principal cells of MEC LII-stellate and pyramidal cells-as they account for $\sim 65 \%-67 \%$ and $17 \%$ of the total cell population in the rat MEC LII, respectively (Gatome et al., 2010). Both cell types have previously been found to exhibit grid cell properties (Tang et al., 2014; Sun et al., 2015). Stellate and pyramidal cells can be identified based on their respective expression of reelin and calbindin, and recent studies have found that the majority of layer II principal neurons are strongly innervated by perisomatic $\mathrm{PV}^{+}$terminals (Armstrong et al., 2016). $\mathrm{PV}^{+}$inhibition of pyramidal cells is, however, controversial. In a recent study, principal cells were classified as stellate, intermediate stellate, pyramidal, and intermediate pyramidal cells, and functional connectivity was observed between $\mathrm{PV}^{+}$cells and all principal cell types except pyramidal cells (Fuchs et al., 2015). This would imply that pyramidal and stellate cells are embedded in completely different inhibitory microcircuits (Witter et al., 2017). A minority of somata at P15 and P30 were not apposed by $\mathrm{PV}^{+}$terminals in the ventral MEC LII; however, we cannot exclude that there are also somata in the dorsal portion with no $\mathrm{PV}^{+}$innervation. It is furthermore possible that the somata without $\mathrm{PV}^{+}$terminal innervation in the cross-sections studied do in fact receive $\mathrm{PV}^{+}$innervation at other levels.

\section{Major $\mathrm{PV}^{+}$basket cell-related network changes before P15}

Rats open their eyes at $\sim 14-15$ days of age (Langston et al., 2010). From as early as P10, somata in dorsal and ventral parts of MEC LII formed symmetrical synapses with terminals containing PV immunoreactivity. In the period between $\mathrm{P} 10$ and $\mathrm{P} 15$, but not between $\mathrm{P} 15$ and $\mathrm{P} 30$, there was an increase in area of cross-sectional somata and amount of $\mathrm{PV}^{+}$terminal apposition, displayed as an increased percentage of cross-sectional somata innervated by $\mathrm{PV}^{+}$terminals and number and density of $\mathrm{PV}^{+}$ terminals per cross-sectional soma. The latter variable, which took into account the total length of $\mathrm{PV}^{+}$terminal membrane apposed to a given cross-sectional soma, was not influenced by the displayed decrease in $\mathrm{PV}^{+}$terminal cross-sectional area between $\mathrm{P} 10$ and P15, suggesting that the effective $\mathrm{PV}^{+}$innervation of LII somata increases before eye opening. This increase could result from two very different developmental phenomena: on the one hand, a later emergence of PV protein expression in pre- viously PV-immunonegative terminals (Seress and Ribak, 1990), and on the other hand, basket cell development to involve large increases in axonal length, axonal collateralizations, and convergence of presynaptic terminals, as other studies have found (Chattopadhyaya et al., 2004; Doischer et al., 2008; Hu et al., 2014). However, considering that $\mathrm{PV}^{+}$terminals at $\mathrm{P} 15$ are smaller than at $\mathrm{P} 10$, it is very well possible that there is a shift that drives the replacement of initial large immature $\mathrm{PV}^{+}$terminals at $\mathrm{P} 10$ with smaller and more numerous $\mathrm{PV}^{+}$terminals at $\mathrm{P} 15$ (Portera-Cailliau et al., 2005).

Interestingly, our results of increased number of $\mathrm{PV}^{+}$ terminals before $\mathrm{P} 15$ are in contrast with data from the mouse primary visual cortex, where the number of $\mathrm{PV}^{+}$ perisomatic terminals was found to increase during a protracted period following eye opening, with a peak at P28 (Chattopadhyaya et al., 2004). As we found these changes to occur mostly before the onset of visual input, it suggests that $\mathrm{PV}^{+}$basket cell-related maturation in MEC LII is largely influenced by intrinsically driven events, which is in keeping with a previous study on the maturation of the entorhinal-hippocampal circuit (Donato et al., 2017).

\section{Synaptic refinement during the emergence of grid cell activity}

There is evidence that the smaller $\mathrm{PV}^{+}$terminals observed at P15 are still immature (Couey et al., 2013). Stellate cells, the most numerous principal cell type in MEC LII (Gatome et al., 2010), are disynaptically connected through $\mathrm{PV}^{+}$interneurons, and a previous study has demonstrated that functional inhibition between $\mathrm{PV}^{+}$ and stellate cells emerges at P16, after which there is an increase in recurrent inhibitory connections and amplitude of inhibition until adult-like levels are reached at P22 (Couey et al., 2013). This follows a similar timeline as the maturation of morphologic, intrinsic, and synaptic properties of hippocampal basket cells (Doischer et al., 2008) and emergence of stable grid cell activity in the rat MEC LII (Langston et al., 2010; Wills et al., 2010, 2012). Grid cells require both excitatory drive from the hippocampus indirectly through deep layers of MEC and direct $\mathrm{PV}^{+}$ inhibition to produce and maintain their hexagonal activity pattern (Bonnevie et al., 2013; Miao et al., 2017); thus, grid cell development is likely paralleled to the development of this presynaptic input. In dorsal and ventral MEC LII, we found no significant changes in cross-sectional area of somata or $\mathrm{PV}^{+}$terminal number and density between $\mathrm{P} 15$ and P30, suggesting that the emergence of fast-spiking $\mathrm{PV}^{+}$basket inhibition in this region is not related to such changes. There was, however, an increase in crosssectional area of $\mathrm{PV}^{+}$terminals. Whether terminal size is related to synaptic strength is not uniform, as both a positive correlation (Schikorski and Stevens, 1997; Mitchell et al., 2012) and no correlation (Branco et al., 2010) have been found between terminal volume and release probability.

In this respect, it is important to emphasize that the dorsal portion of MEC LII in one P30 animal displayed cells with, on average, a significantly lower number of $\mathrm{PV}^{+}$ 
terminals as well as $\mathrm{PV}^{+}$terminals with larger crosssectional area than the other P30 animal. This may be a result of the limitations in sampling $\mathrm{PV}^{+}$terminals from thin sections. The results should be considered as approximative or semiquantitative, since the cells are not completely regular in shape or distribution around the soma (Chattopadhyaya et al., 2004; Ledoux and Woolley, 2005). It may also be due to an uneven sampling of cell types that are apposed by different numbers of $\mathrm{PV}^{+}$ perisomatic terminals (Armstrong et al., 2016). A third reason could be that somata in MEC LII in the two animals are differently innervated by $\mathrm{PV}^{+}$terminals at P30, as the maturational process for the generation and elimination of synaptic contacts is highly dynamic (Portera-Cailliau et al., 2005).

Another aspect showing maturational changes between P15 and P30 was the percentage of dorsal and ventral $\mathrm{PV}^{+}$terminals containing mitochondria, which increased from $30 \%-40 \%$ to $60 \%-70 \%$. This percentage at P30 is similar to perisomatic inhibitory terminals innervating CA1 pyramidal neurons in the adult rat, where $76 \%$ were found to contain mitochondria (Ledoux and Woolley, 2005). Mitochondria in presynaptic terminals play several important roles, one of which is to mobilize vesicles from the reserve pool to replenish the readily release pool (Devine and Kittler, 2018). The size of the readily release pool is positively correlated with release probability (Dobrunz and Stevens, 1997; Murthy et al., 2001; Branco et al., 2010), and a study has shown that dynamin-related protein 1 (Drp1) knockout in flies, which leads to a reduced amount of terminal mitochondria, impairs synaptic transmission when stimulated at high frequency (Verstreken et al., 2005). A larger presence of mitochondria in $\mathrm{PV}^{+}$terminals may therefore reflect an increased need for a machinery to support its fast-spiking characteristics necessary for proper grid cell activity.

\section{Dorsoventral differences in the development of $\mathrm{PV}^{+}$ basket cell synaptic circuitry}

MEC LIl displays gradients along the dorsoventral axis (DVA) in a number of ways: first, a physiologic larger grid field size and spacing and frequency of theta modulation (Brun et al., 2008); second, a reduction in size of stellate cells and increase in rise time and half-width of spontaneous excitatory postsynaptic potentials (Garden et al., 2008); third, a lower frequency of $\mathrm{PV}^{+}$inhibitory inputs onto stellate cells and overall lower number of $\mathrm{PV}^{+}$terminals (Beed et al., 2013); and fourth, a delayed development of the ventral part compared to the dorsal (Ray and Brecht, 2016; Donato et al., 2017). To investigate potential gradients in $\mathrm{PV}^{+}$basket cell synaptic circuitry along the DVA, we compared $\mathrm{PV}^{+}$terminals and target somata in the dorsal-most region of LIl with the ventral-most region.

At all developmental stages, ventral somata were smaller and apposed by fewer $\mathrm{PV}^{+}$terminals than in the dorsal portion. The morphology of dorsal and ventral $\mathrm{PV}^{+}$ terminals was, however, remarkably similar. Dorsoventral differences in soma size and amount of $\mathrm{PV}^{+}$perisomatic innervation were present already at P10, suggesting that the development of the $\mathrm{PV}^{+}$basket cell-related network is delayed in the ventral compared to the dorsal region, which is in close agreement with previous studies reporting a gradient of maturation along the DVA (Ray and Brecht, 2016; Donato et al., 2017). Based on colocalization of doublecortin, a marker for immature neurons, it was found that $>80 \%$ of dorsal $\mathrm{PV}^{+}$cells and $\sim 40 \%$ of ventral $\mathrm{PV}^{+}$cells in mice are mature at P20 in MEC LII (Donato et al., 2017).

Larger somata and more numerous perisomatic $\mathrm{PV}^{+}$ terminals in dorsal LII are in keeping with studies reporting a gradient in size of stellate somata and number of $\mathrm{PV}^{+}$ terminals along the DVA (Garden et al., 2008; Beed et al., 2013). $\mathrm{PV}^{+}$basket cells make up $\sim 60 \%$ of the total $\mathrm{PV}^{+}$ population; however, $\mathrm{PV}^{+}$interneurons also comprise subtypes targeting the axon initial segments and distal dendrites of neurons. Moreover, $\mathrm{PV}^{+}$basket cells target proximal dendrites as well as somata (Klausberger et al., 2003; Baude et al., 2007). Our results therefore indicate that the decrease in $\mathrm{PV}^{+}$terminal number is at least partly due to fewer perisomatic $\mathrm{PV}^{+}$terminals. Interestingly, it was found that dorsal stellate cells receive inhibition from $\mathrm{PV}^{+}$cells that are both proximal, closer than $100 \mu \mathrm{m}$, and distal, $>100 \mu \mathrm{m}$ away. In contrast, ventral stellate cells are mainly targeted by proximal $\mathrm{PV}^{+}$cells (Beed et al., 2013). This could imply that the larger number of perisomatic terminals on dorsal somata is not a result of a larger number of terminals originating from single $\mathrm{PV}^{+}$cells, but rather a larger number of distinct $\mathrm{PV}^{+}$cells innervating dorsal somata. Furthermore, our results indicate that $\mathrm{PV}^{+}$ terminals in the ventral portion of LII at P30 are on average smaller than in the dorsal portion. If the number of active zones scales up with terminal size (Schikorski and Stevens, 1997), it is possible that the release probability of dorsal $\mathrm{PV}^{+}$perisomatic terminals is greater than ventral ones.

We cannot exclude that there are structural changes in LII somata and perisomatic $\mathrm{PV}^{+}$terminals after $\mathrm{P} 30$, or that the reported dorsoventral differences are lost in the adult. A previous study on PV immunoreactivity in adult rats found up to six $\mathrm{PV}^{+}$terminals per soma per thin section in MEC LII (Wouterlood et al., 1995), whereas we found up to 15 at P30. However, an absence of significant changes in cross-sectional soma area and amount of $\mathrm{PV}^{+}$ innervation between P15 and P30 suggest that these structural features stabilize during this time period, such that the dorsoventral differences in soma size and amount of $\mathrm{PV}^{+}$innervation is maintained in the mature MEC LII. This is in line with the decreased size of stellate somata found along the DVA in the adult mouse (Garden et al., 2008).

\section{Functional relevance}

Inhibitory inputs from fast-spiking $\mathrm{PV}^{+}$cells have been found to be critical for the maintenance of the spatial modulation of grid cells (Buetfering et al., 2014; Miao et al., 2017), which is present from P16 onwards (Langston et al., 2010; Wills et al., 2010, 2012). Our findings suggest that grid cell activity emergence is linked to a strengthening of $\mathrm{PV}^{+}$terminals by increased terminal size and presence of mitochondria after soma size and num- 
ber and density of apposing $\mathrm{PV}^{+}$terminals have stabilized. Furthermore, our data indicate that ventral somata are smaller and apposed by fewer and smaller $\mathrm{PV}^{+}$terminals compared with dorsal somata at P30. This suggests that there is a gradient in the organization of MEC LII microcircuits along the DVA, which is in accordance with the decreased $\mathrm{PV}^{+}$inhibition and theta modulation as well as increased grid field size and spacing toward the ventral part of LII (Brun et al., 2008; Beed et al., 2013).

\section{References}

Armstrong C, Wang J, Yeun Lee S, Broderick J, Bezaire MJ, Lee S-H, Soltesz I, (2016) Target-selectivity of parvalbumin-positive interneurons in layer II of medial entorhinal cortex in normal and epileptic animals. Hippocampus 26:779-793. CrossRef Medline

Baude A, Bleasdale C, Dalezios Y, Somogyi P, Klausberger T, (2007) Immunoreactivity for the GABAA receptor alpha1 subunit, somatostatin and Connexin36 distinguishes axoaxonic, basket, and bistratified interneurons of the rat hippocampus. Cereb Cortex 17:2094-2107. CrossRef Medline

Beed P, Gundlfinger A, Schneiderbauer S, Song J, Böhm C, Burgalossi A, Brecht M, Vida I, Schmitz D, (2013) Inhibitory gradient along the dorsoventral axis in the medial entorhinal cortex. Neuron 79:1197-1207. CrossRef Medline

Bonnevie T, Dunn B, Fyhn M, Hafting T, Derdikman D, Kubie JL, Roudi Y, Moser El, Moser M-B, (2013) Grid cells require excitatory drive from the hippocampus. Nat Neurosci 16:309-317. CrossRef Medline

Branco T, Marra V, Staras K, (2010) Examining size-strength relationships at hippocampal synapses using an ultrastructural measurement of synaptic release probability. J Struct Biol 172:203210. CrossRef Medline

Brun VH, Solstad T, Kjelstrup KB, Fyhn M, Witter MP, Moser El, Moser M-B, (2008) Progressive increase in grid scale from dorsal to ventral medial entorhinal cortex. Hippocampus 18:1200-1212. CrossRef Medline

Buetfering C, Allen K, Monyer H, (2014) Parvalbumin interneurons provide grid cell-driven recurrent inhibition in the medial entorhinal cortex. Nat Neurosci 17:710-718. CrossRef Medline

Chattopadhyaya B, Di Cristo G, Higashiyama H, Knott GW, Kuhlman SJ, Welker E, Huang ZJ, (2004) Experience and activity-dependent maturation of perisomatic GABAergic innervation in primary visual cortex during a postnatal critical period. J Neurosci 24:9598-9611. CrossRef Medline

Couey JJ, Witoelar A, Zhang S-J, Zheng K, Ye J, Dunn B, Czajkowski R, Moser M-B, Moser El, Roudi Y, Witter MP, (2013) Recurrent inhibitory circuitry as a mechanism for grid formation. Nat Neurosci 16:318-324. CrossRef Medline

Devine MJ, Kittler JT, (2018) Mitochondria at the neuronal presynapse in health and disease. Nat Rev Neurosci 19:63-80. CrossRef Medline

Dobrunz LE, Stevens CF, (1997) Heterogeneity of release probability, facilitation, and depletion at central synapses. Neuron 18:9951008. Medline

Doischer D, Aurel Hosp J, Yanagawa Y, Obata K, Jonas P, Vida I, Bartos M, (2008) Postnatal differentiation of basket cells from slow to fast signaling devices. J Neurosci 28:12956-12968. CrossRef

Donato F, Jacobsen RI, Moser MB, Moser El, (2017) Stellate cells drive maturation of the entorhinal-hippocampal circuit. Science 355:eaai8178. CrossRef

Fuchs EC, Neitz A, Pinna R, Melzer S, Caputi A, Monyer H, (2015) Local and distant input controlling excitation in layer II of the medial entorhinal cortex. Neuron 89:194-208. CrossRef Medline

Garden DLF, Dodson PD, O’Donnell C, White MD, Nolan MF, (2008) Tuning of synaptic integration in the medial entorhinal cortex to the organization of grid cell firing fields. Neuron 60:875-889. CrossRef

Gatome CW, Slomianka L, Lipp HP, Amrein I, (2010) Number estimates of neuronal phenotypes in layer II of the medial entorhinal cortex of rat and mouse. Neuroscience 170:156-165. CrossRef Medline

Hafting T, Fyhn M, Molden S, Moser M-B, Moser El, (2005) Microstructure of a spatial map in the entorhinal cortex. Nature 436:801806. CrossRef Medline

Hu H, Gan J, Jonas P, (2014) Fast-spiking, parvalbumin + GABAergic interneurons: from cellular design to microcircuit function. Science 345:1255263. CrossRef Medline

Kjonigsen LJ, Lillehaug S, Bjaalie JG, Witter MP, Leergaard TB, (2015) Waxholm Space atlas of the rat brain hippocampal region: three-dimensional delineations based on magnetic resonance and diffusion tensor imaging. Neuroimage 108:441-449. CrossRef Medline

Klausberger T, Magill PJ, Márton LF, Roberts JDB, Cobden PM, Buzsáki G, Somogyi P, (2003) Brain-state- and cell-type-specific firing of hippocampal interneurons in vivo. Nature 421:844-848. CrossRef

Langston RF, Ainge JA, Couey JJ, Canto CB, Bjerknes TL, Witter MP, Moser El, Moser M-B, (2010) Development of the spatial representation system in the rat. Science 328:1576-1580. CrossRef Medline

Ledoux VA, Woolley CS, (2005) Evidence that disinhibition is associated with a decrease in number of vesicles available for release at inhibitory synapses. J Neurosci 25:971-976. CrossRef Medline

Miao C, Cao Q, Moser M-B, Moser El, (2017) Parvalbumin and somatostatin interneurons control different space-coding networks in the medial entorhinal cortex. Cell 171:507-521. CrossRef Medline

Mitchell N, Petralia RS, Currier DG, Wang Y-X, Kim A, Mattson MP, Yao PJ, (2012) Sonic hedgehog regulates presynaptic terminal size, ultrastructure and function in hippocampal neurons. J Cell Sci 125:4207-4213. CrossRef Medline

Moser El, Kropff E, Moser M-B, (2008) Place cells, grid cells, and the brain's spatial representation system. Annu Rev Neurosci 31:6989. CrossRef Medline

Murthy VN, Schikorski T, Stevens CF, Zhu Y, (2001) Inactivity produces increases in neurotransmitter release and synapse size. Neuron 32:673-682. Medline

Papp EA, Leergaard TB, Calabrese E, Johnson GA, Bjaalie JG, (2014) Waxholm Space atlas of the Sprague Dawley rat brain. Neuroimage 97:374-386. CrossRef

Pastoll H, Solanka L, van Rossum MCW, Nolan MF, (2013) Feedback inhibition enables theta-nested gamma oscillations and grid firing fields. Neuron 77:141-154. CrossRef

Portera-Cailliau C, Weimer RM, De Paola V, Caroni P, Svoboda K, (2005) Diverse modes of axon elaboration in the developing neocortex. PLoS Biol 3:e272. CrossRef Medline

Puchades MA, Csucs G, Checinska M, Øvsthus M, Bjerke IE, Andersson K, Leergaard TB, Bjaalie JG, (2017) QuickNII: Neuroinformatics tool and workflow for anchoring of serial histological images in rodent brain 3D space. In: Neuroscience Meeting Planner. Washington, DC: Society for Neuroscience.

Ray S, Brecht M, (2016) Structural development and dorsoventral maturation of the medial entorhinal cortex. eLife 5:e13343. CrossRef Medline

Schikorski T, Stevens CF, (1997) Quantitative ultrastructural analysis of hippocampal excitatory synapses. J Neurosci 17:5858-5867. Medline

Seress L, Ribak C, (1990) Postnatal development of the light and electron microscopic features of basket cells in the hippocampal dentate gyrus of the rat. Anat Embryol 181:547-565. Medline

Stensola H, Stensola T, Solstad T, Frøland K, Moser M-B, Moser El, (2012) The entorhinal grid map is discretized. Nature 492:72-78. CrossRef Medline

Sun C, Kitamura T, Yamamoto J, Martin J, Pignatelli M, Kitch LJ, Schnitzer MJ, Tonegawa S, (2015) Distinct speed dependence of entorhinal island and ocean cells, including respective grid cells. Proc Natl Acad Sci U S A 112:9466-9471. CrossRef Medline

Tang Q, Burgalossi A, Ebbesen CL, Ray S, Naumann R, Schmidt H, Spicher D, Brecht M, (2014) Pyramidal and stellate cell specificity 
of grid and border representations in layer 2 of medial entorhinal cortex. Neuron 84:1191-1197. CrossRef Medline

van den Pol AN, Gorcs T, (1986) Synaptic relationships between neurons containing vasopressin, gastrin-releasing peptide, vasoactive intestinal polypeptide, and glutamate decarboxylase immunoreactivity in the suprachiasmatic nucleus: dual ultrastructural immunocytochemistry with gold-su. J Comp Neur 252:507-521. CrossRef Medline

Verstreken P, Ly CV, Venken KJT, Koh T-W, Zhou Y, Bellen HJ, (2005) Synaptic mitochondria are critical for mobilization of reserve pool vesicles at Drosophila neuromuscular junctions. Neuron 47: 365-378. CrossRef

Wills TJ, Barry C, Cacucci F, (2012) The abrupt development of adult-like grid cell firing in the medial entorhinal cortex. Front Neural Circuits 6:21. CrossRef Medline

Wills TJ, Cacucci F, Burgess N, O'Keefe J, (2010) Development of the hippocampal cognitive map in preweanling rats. Science 328: 1573-1576. CrossRef Medline

Witter MP, Doan TP, Jacobsen B, Nilssen ES, Ohara S, (2017) Architecture of the entorhinal cortex: a review of entorhinal anatomy in rodents with some comparative notes. Front Syst Neurosci 11:46. CrossRef Medline

Wouterlood FG, Härtig W, Brückner G, Witter MP, (1995) Parvalbumin-immunoreactive neurons in the entorhinal cortex of the rat: localization, morphology, connectivity and ultrastructure. $J$ Neurocytol 24:135-153. Medline 